\title{
Vocatives with determiners: the case of vocatives preceded by possessives ${ }^{*}$
}

\author{
Laura González López \\ Universidad Castilla-La Mancha \\ profesor.lgonzalez@uclm.es
}

Received: 27-10-2017

Accepted: 11-05-2018

\begin{abstract}
In some varieties of Spanish (American, above all), possessives can appear in vocative constructions such as Mi niña, ¿qué haces? (lit. 'My girl, what are you doing?') in contrast to the generalization that vocatives refuse determiners (Bosque 1996, Leonetti 1999, 2016). The aim of this investigation is to explicate why this occurs and to propose a syntactic analysis that accounts for these cases and reflects the data obtained by some spoken (PRESSEA) and written corpora (CREA). The analysis is based on the accounts developed by Leonetti (1999) and Eguren (to appear) for possessives, and Espinal (2013) and Hill (2013b) for vocatives. The conclusions obtained in this paper predict that in those varieties in which possessives are compatible with determiners (e.g. un mi amigo, lit. 'a my friend'), we obtain a prenominal possessive in vocatives (e.g. $m i$ amigo, lit. 'my friend') as a result of the possessive's movement to [Specifier, AgrP] (e.g. amigo $\underline{\text { mío }}>\underline{m i_{i}}$ amigo $\mathrm{h}_{\mathrm{i}}$ ). In contrast, in those varieties where possessives are not compatible with them (e.g. un amigo mio, lit. 'a friend mine'), we find a postnominal possessive in vocative constructions (e.g. amigo mio, lit. 'friend mine'). Hence, the purpose of this paper is to present an analysis of vocatives usually disregarded in grammatical studies.
\end{abstract}

Keywords: vocatives, possessives, Spanish variation, syntactic analysis, corpus.

I want to thank my PhD supervisor, Cristina Sánchez López, for her help and support in every step I have taken in this investigation. Of course, any mistakes are my own. 


\section{Table of Contents}

\section{0 . Introduction}

1. Vocatives: some important properties

2. Data

3. Hypotheses

3.1. Vocatives in Spanish must be bare

3.2. Possessive vocatives in Spanish are fake vocatives

\author{
3.3. Possessives in non-bare \\ vocatives are not real determiners \\ 4. Analysis \\ 4.1. Vocatives with postnominal \\ possessives \\ 4.2. Vocatives with a prenominal \\ possessive
}

5. Conclusion and future research

References

\section{Introduction}

It is a well-known fact in numerous of investigations (Leonetti 1999; Alonso Cortés 1999: §12; and Bosque 1996, among others) that vocatives cannot be headed by a determiner, as can be seen in the following examples:
a. Amigo, no tengas miedo.
friend.voc, not have fear
'Friend/Man, don't be afraid'
b. $\quad *\{\mathrm{El} / \mathrm{Un} /$ Este/Ese/Aquel... $\}$ amigo, the/a/this/that/that friend.voc,
no tengas miedo. ${ }^{1}$
'(intended) Friend/Man, don't be afraid'.
not have fear

Nevertheless, in some Spanish varieties, especially those in Latin American, we find cases where a special determiner (i.e. possessive) appears in vocative constructions:

$\begin{array}{ll}M i \text { amigo, no tengas miedo. } \\ \text { my friend.voc not have fear } \\ \text { 'My friend, don't be afraid' } \\ \text { Vuelve a casa, } & \text { mi hijo. } \\ \text { come.IMP to home } & \text { my son.voC } \\ \text { 'Come back home, my son' } & \end{array}$

The questions that arise are clear:

(1) How can we explain the data?

(2) Does it mean that the above generalization is incorrect and needs to be reformulated?

1 There are however some examples where determiners are possible: El chico de la última fila, salga al estrado ('The boy in the last row, go to the platform'). We are not going to examine these cases, but some investigations suggest the possible existence of a null addressee ( $\varnothing$ addr), whose features $\left(2^{\text {nd }}\right.$ person) could be the reason for coindexing with another element inside the sentence ([Øaddr ${ }_{i}$ María], ¿te $e_{i}$ ayudo?). Nevertheless, more data are necessary to confirm or disprove it. 
(3) What are the properties of possessives that allow them to combine with vocatives?

(4) How can these conclusions affect the syntactic analysis of vocatives?

The goal of the present study is to explain why these constructions are possible in vocatives and what repercussions this has on our proposal. To that end, the paper is organized into five sections. The first section offers basic of vocatives and summarizes their main properties, while the second illustrates the data found in some Spanish varieties. The third section tries to answer the question of whether the previous generalization is (in)correct and whether it is necessary to reformulate it. Once we have chosen and justified which hypothesis is the most appropriate, in section four a syntactic analysis is proposed that reflects the properties of vocatives, while paying special attention to the representation within which possessives are included. Finally, in section five we will draw some conclusions and point out some future avenues of research.

\section{Vocatives: some important properties}

Before we begin to answer the questions raised in the previous section, it is necessary to define vocatives RAE (i.e. Real Academia Española) proposes the following definition:

[Son] expresiones vocativas los nombres, los pronombres y los grupos nominales que se usan para llamar a las personas o animales (;Eh, tú!; ¡Papá!; ¿me oís?; Lucera, ven acá) para iniciar un intercambio verbal o para dirigir a alguien un saludo (¡Hola, Clara!), una pregunta (¿Está cansado, don Marcelo?), una petición o una orden (Márchate, niña), una advertencia (Manuel, ten cuidado), una disculpa (Lo siento, caballero), etc. (RAE y ASALE 2009: $\$ 32.2 \mathrm{~g})^{2}$.

As a consequence, it is fair to assume that vocatives are generally nominal elements - though in some cases they can be adjectives too (e.g. iInfeliz, ven aquí!, lit. 'Miserable/Naïve, come here!') - that do not take part in the syntactic structure, and that serve to draw the attention of the hearer or to maintain the contact with him or her (Zwicky 1974: 787). Such constructions are characterized by some important properties. One of them is their deictic second person (singular or plural) features as a result of their relation with the addressee. Hill (2013b) is one of the authors who points this out:

(...) the addressee has an inherent second person feature (Fink 1972; Variel 1981) and inherent reference, the latter coming either from lexical or deictic information. This means that the addressee (and the vocative construction that lexicalizes it) has intrinsic specificity. Thus, second person pronouns are prime

2 "Vocatives expressions are nouns, pronouns and nominal groups used to call people or animals (Sp. ¡Eh, tú! /Engl. Hey, you!; Sp. ¡Papá!, ¿me oís? / Engl. Dad, can you hear me?; Sp. Lucera, ven acá / Eng. Lucera, come here) to start a verbal exchange or to greet someone (sp. ¡Hola, Clara! / Engl. Hi, Clara!), a question (Sp. ¿Está cansado, don Marcelo? /Engl. Are you tired, Mr. Marcelo?), a request or an order (Sp. Márchate, niña, / Engl. Get out, girl'), an apology (Sp. Lo siento, caballero/ Engl. I'm sorry, sir), etc.” (RAE y ASALE 2009: §32.2g). 
candidates for Vocative Phrases, since they can receive their reference deictically (Hill 2013b: 58).

Therefore, we can say that vocatives have deictic and personal features (specifically second person, either singular or plural) and, as a consequence, referential ability, since they refer to specific addressees or a set of them. Some examples in this regard are given in (4):
a. María, busca a tu hermana (María = tú). María.VOC find.IMP to your sister
b. Ana y Luis, 'María, find your sister' (María = you)
Ana.VOC and Luis.VOC find.IMP.PL
a vuestros hermanos (Ana y Luis $=$ vosotros).
to your.PL brothers
'Ana and Luis, find your brothers' (Ana y Luis = you)

Another important property of vocatives is their specificity. According to Leonetti (1999), specificity can be understood in three different senses: logical, discursive and pragmatic ${ }^{3}$ (Leonetti 1999: $§ 12.3 .2 .1$ ). The pragmatic criterion, the most common and intuitive, will be taken into account in this investigation since it supposes that a Noun Phrase (NP) is specific when it is employed by the speaker to refer to a certain entity of which (s)he is thinking (Leonetti 1999: $\S 12.3 .2 .1$.). Hence, when we say desgraciados ('wretches') or niños ('kids') as in (5a) and (5b) respectively, we are referring to a specific set of individuals who receive, in this case, the order of the speaker. If the interpretation is not specific, then any person who fulfills the condition of being miserable or of being young would attend the speaker's call. Therefore, vocatives refer to specific entities despite having indefinite forms:
Wretches.VOC not run.IMP.PL
'Wretches, don't run!'
a. ¡Desgraciados, no corráis!
b. Niños, venid a recoger la mesa.
Kids.VOC come.IMP.PL to clear the table
'Kids, come clear the table'

Vocatives also have the capacity for movement, since they can appear in three different positions: initial (6a), medial (6b) or final (6c). They share this property with peripheral adverbs ((7a), (7b) and (7c) respectively)) as Bañón (1993) and Alonso Cortés (1999: §62.8.5.3.) point out for Spanish, and Leech (1999) for English, and they can even co-occur with them (8):
(6) a. María, me encantaría que vinieras.
María.vOC, me.ACC love.COND that come.SUBJ.2sG
'María, I would love you to come' 3 For more information about specificity types see Lyons (1977) and Leonetti
$(1990,1999)$ and references therein. 


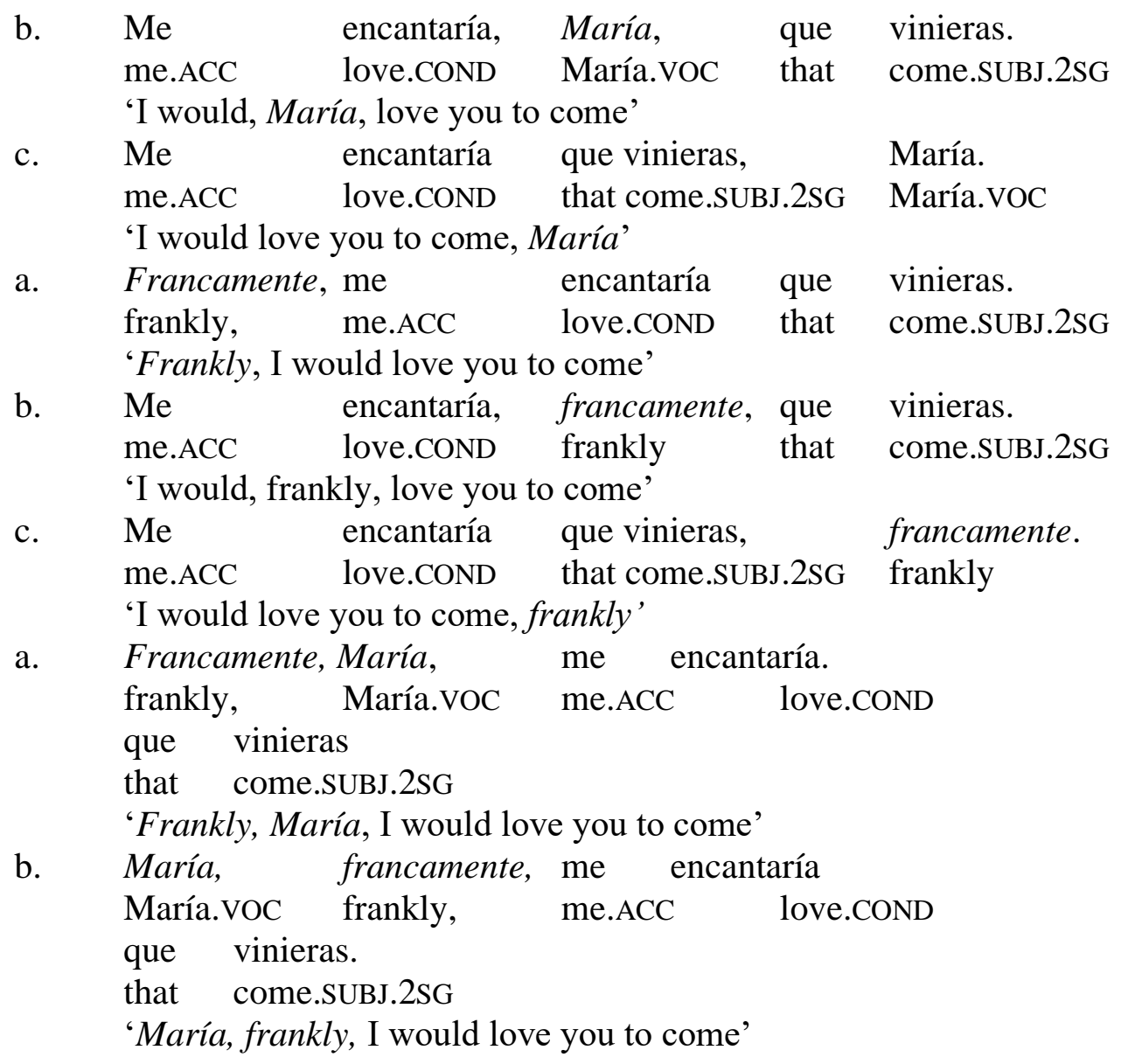

Besides these syntactic properties, vocatives are also characterized by having some pragmatic properties. In this respect, Hill (2012, 2013a, 2013b), Haegeman \& Hill (2013) and Haegeman (2014) postulate the existence of a feature that contains all the properties associated with the type of relationship between the speaker and the hearer: familiarity, respect, politeness, etc. For instance, if Sir is used as a vocative (Sir, can I help you?) instead of man (Man, can I help you?), we are indicating that the type of relationship between the speaker and the hearer is one of respect (possibly due to an age difference), distance, and politeness among others. In contrast, if man were used, the opposite would be exhibited: familiarity, proximity, informal context, etc. Haegeman and Hill call this feature inter-personal, which triggers some syntax operations, such as agreement effects between optional Vocative Particles and vocative nouns (9) or the option for Case assignment ((10) and (11)), among others (Hill 2013b: 53). In (9), (10) and (11) some cases are presented in this regard:

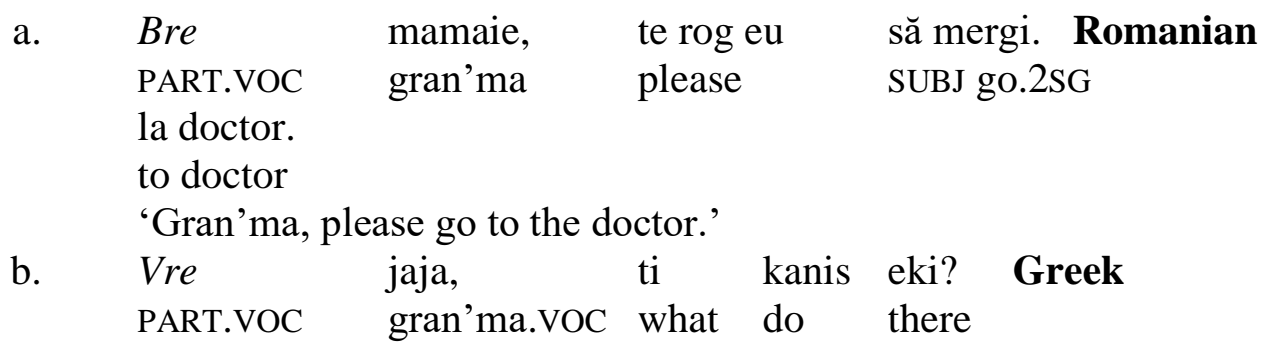


'Gran'ma, what are you doing there?'
a. măi
PART.VOC
b. Radu, ...
Radu(VOC)

Radule, ...

$\begin{array}{ll}\text { (măi) } & \text { Radule, ... } \\ \text { PART.VOC } & \text { Radu.DEF.VOC }\end{array}$

(Hill 2013b: 53)
= informal Romanian
$=$ formal

(Hill 2013b: 55)

= informal Romanian

(Hill, 2013b: 55)

As shown in (9)-(10), măi and bre are used in "standard colloquial register" and so denote "polite informality" (Hill, 2013b: 54). As a consequence, the choice of particle depends on the type of relationship between the speaker and listener, that is, to their inter-personal feature. Something similar occurs in (10) when the presence of the particle măi together with the vocative case ending $-e$ produces an informal interpretation (10a), just the opposite of what happens when the vocative case is not marked (10b). In the informal variety, the article is present as shown in (11), but it is absent in formal varieties, see (10b). Therefore, it can be claimed that the inter-personal feature has repercussions in the syntax.

Vocatives also have some semantic restrictions as Alonso Cortés (1999: §62.8.5.2.) and Leech (1999) propose for Spanish and English respectively. These restrictions are related to the types of nouns that may be employed as vocatives According to the research mentioned, these nouns are the following ${ }^{4}$ :

(a) proper nouns and hypocoristics: Pepe, Lola, Asun,

(b) patronymics: Sánchez, Martínez, López,

(c) demonyms: español, americano, francés ('Spanish', 'American' and 'French' respectively),

(d) kinship names: papá, mamá, tío(a), abuelo(a) ('dad', 'mum, uncle/aunt', 'grandma/grandpa', respectively),

(e) nouns that denote age: niño, joven, chaval, viejo ('kid', 'old man'),

(f) nicknames: tirillas,

(g) nouns that denote intimate treatment: colega ('colleague'), vida ('love'), corazón ('love'), cielo ('honey'),

(h) titles (hierarchy names): señorita ('lady'), señora ('madam'), joven ('young'), profesor ('teacher, professor'), doctor ('doctor'), jefe ('boss'), alteza ('Highness'), majestad ('Majesty'), capitán ('captain'), sargento ('sergeant'),

(i) professional names: chófer ('chauffeur, driver'), portero ('doorman'), taxista ('taxi driver'), camarero ('waiter'), guardia ('security guard').

Lastly, we would point out one of the properties of vocatives that will have the most impact in this research: they cannot be headed by determiners (Bosque 1996; Leonetti 1999, 2016), at least in Spanish (cf. Moro 2003; Stavrou 2014). Some examples in this respect are offered in (12):

\footnotetext{
$4 \quad$ We will take this classification into account in the next section in order to organize the data found in some varieties of Spanish.
} 

a. Amigo, no tengas miedo. friend.VOC, not have fear. 'Friend/Man, don't be afraid'
b. $\quad *\{$ El/Un/Este/Ese/Aquel... $\}$ amigo, \{the/a/this/that/that...\} friend.voC not have miedo. '(intended) $\{$ The/A/This/That... $\}$ friend, don't be afraid'

That vocatives cannot be headed by a determiner has been used as a diagnostic to see if a particular word is a determiner or an adjective. For instance, Eguren and Sánchez López $(2003,2007)$ aim to demonstrate that cierto ('certain') and otro ('(an)other') are, in fact, determiners and in order to argue for this, they make use of this diagnostic:
a. Niña linda, ven aquí. girl pretty.VOC come.IMP here 'Pretty girl, come here'
b. $*\{$ La/Una/Esta/Esa/Aquella $\}$ niña, ven aquí. \{the/a/this/that/that $\}$ pretty.VOC come.IMP here '(intended) $\{$ The/A/This/That $\}$ girl, come here'
a. * Cierta niña, ven aquí. certain girl.VOC come.IMP here
'(intended) Girl, come here'
b. *Otra niña, ven aquí. other girl.vOC come.IMP here '(intended) (An)other girl, come here'

As is noted in (13), vocatives can combine with adjectives (13a), but not with determiners (13b). Thus, if cierto and otro were adjectives, they could appear in these constructions. However, they cannot, as (14) shows, which leads Eguren and Sánchez López to conclude that cierto and otro are, in these cases, true determiners, and not adjectives.

The vocatives' inability to combine with determiners contrasts with that of the preverbal subject, since the latter has to be introduced by a Determiner Phrase (DP), as Longobardi (1994: 620) points out: “A 'nominal expression' is an argument only if it is introduced by a category D" . Therefore, we cannot have examples like (15a), since preverbal subjects have to be inserted in a DP if they want to be referential expressions (for postnominal subjects without determination, see Bosque 1996). On the contrary, vocatives are referential but they do not admit determiners, as we see in $(15 \mathrm{~b})$ :

$$
\begin{aligned}
& \text { a. } *(\mathrm{El}) \text { doctor le dio un consejo a la paciente. } \\
& \text { the doctor him.DAT gave an advice to the patient } \\
& \text { '*(The) doctor gave some advice to the patient' }
\end{aligned}
$$

5 This generalization is later nuanced by Longobardi by saying that "DP can be an argument, NP cannot" (Longobardi 1994: 628). In this article we are not going to discuss why vocatives, in spite of being predicates, are DPs and not NPs. However, the reader is referred to see D'hulst, Coene \& Tasmowski (2007) and references therein. 
b. (*El) doctor, ¿me puede dar un consejo? the doctor.VOC, me.DATcan give.INF an advice? '(*The) doctor, can you give me some advice?'

In light of these data, the following generalization can be established:

"In Spanish, vocative constructions cannot be headed by any determiner"6

Nevertheless, we find some counterexamples to this generalization in some Spanish varieties where vocatives can be headed by a specific determiner: the possessive. In the next section I discuss what happens in these varieties and how it can be explained.

\section{Data}

As shown at the end of the previous section, it is a well-known phenomenon that vocatives are not compatible with any type of determiners (Longobardi 1994, Bosque 1996 and Leonetti 1999). Therefore, examples like (17b) and (17c) should not be found in any corpus:
a. Chicos, es hora de cenar. boys/guys.VOC is time of dinner 'Boys/Guys, it is dinner time'
b. $*\{$ Los/Unos $\}$ chicos, es hora de cenar. \{the/some\} boys/guys.VOC is time of dinner '(intended) The/some boys/guys, it is dinner time'
c. $*\{$ Esos/Estos/Aquellos $\} \quad$ chicos, es hora de cenar. \{those/these/those \} boys/guys.VOC is time of dinner '(intended) These/those boys/guys, it is dinner time'

However, in some Spanish varieties (above all, Latin-American) some examples have been detected in this regard. According to the classification presented in section 1, the types of nouns that can be combined with possessives are restricted to kinship names (18), titles or hierarchy nouns (19), and nouns that denote intimate treatment $(20)^{7}$ :

$6 \quad$ Nevertheless, as Moro (2003) points out, this generalization is not sufficient to identify vocatives, since some languages like French (Stavrou 2014) and Romanian (Hill 2012, 2013a, 2013b) admit determiners in vocative constructions.

7 The question that arises is why there are restrictions regarding the types of vocative nouns that allow possessives. Although it would need deeper investigation, it may be due to the fact that the nouns that appear in these contexts should establish a type of relationship between speaker and listener. For example, the construction mi hijo ('my son') is used to mark the kinship between a father or mother with his/her son, mi jefe ('my boss') to indicate a type of hierarchy (from a lower to a higher position), and mi vida ('my life') to show affection between two people. Therefore, in these constructions it seems necessary to mark the relationship between the speaker and the listener in some way, either because 
(18) Volveremos a llevarnos esas tablas, mi amigo (Perú, CREA, 1993). return.FUT to take-us.DAT those tables my friend.VOC

'We will take those tables back, my friend'
Mi sargento,
aquí hay
sangre, uno va

my sergeant.vOC

here there-is

blood one goes

herido (España, CREA, 2002).

injured

'My sergeant, there is blood here, one is injured'
Mi amor, ponte derecha, y no suenes más
my love.VOC put-you straight, and not sound more
la patineta (Venezuela, ORAL, CREA).
the scooter'
'My love, stand up straight, and don't make any more noise with the scooter'

Examples (18)-(20) raise two important questions regarding the extension of the phenomenon: first, among dialects and, second, within dialects. To answer these questions, two different corpora have been analyzed: PRESSEA and $\mathrm{CREA}^{8}$. The results obtained are presented in Table 1.

they have some kind of relationship of kinship, power or affection. Proof of this comes from the very form of these constructions: they are headed by a possessive in first person of singular, $m i$ ('my'), which is associated with the speaker, followed by a noun that establishes the type of relationship between the speaker and the listener. As a consequence, if the noun cannot represent any kind of relationship, it would not appear in these constructions (*Mi español, muévete: 'My Spanish, move').

An important caveat is in place here: the data obtained are partial, not conclusive since CREA and PRESSEA do not have the same number of examples of each variety. For instance, in CREA only half of the data comes from America. If we convert that $50 \%$ into $100 \%, 40 \%$ is from the Mexican zone (Mexico, southwestern United States, Guatemala, Honduras, El Salvador), 20\% from the Andean region, Venezuela, Colombia, Ecuador, Peru and Bolivia), 17\% from the Caribbean (Cuba, Puerto Rico, Panama, Dominican Republic, the coasts of Venezuela and Colombia, and north-eastern United States), $14 \%$ from the River Platte area (Argentina, Paraguay and Uruguay), 6\% from Chile, and 3\% from the central zone (Nicaragua and Costa Rica) (data taken from CREA). In PRESSEA, the data are collected from Caracas, Guadalajara, Havana, Lima, Medellin, Mexico DF, Monterrey, Montevideo and Santiago de Chile. As a consequence, although these data are not conclusive, they are very useful to show trends and give us some clues about the behaviour of these constructions in the Spanish used in the Americas. 


\begin{tabular}{|c|c|c|c|c|c|c|c|c|c|c|c|}
\hline & \multicolumn{3}{|c|}{ KINSHIPNAMES } & \multicolumn{3}{|c|}{ TITLES } & \multicolumn{5}{|c|}{ INTIMATE TREATMENT } \\
\hline & $\begin{array}{l}\text { Hijo/ } \\
-a\end{array}$ & $\begin{array}{l}\text { Amigo/ } \\
-a\end{array}$ & $\begin{array}{l}\text { Hermano/ } \\
-a\end{array}$ & Jefe & $\begin{array}{l}\text { Señor } \\
\text { /- } a\end{array}$ & $\begin{array}{l}\text { Sargen- } \\
\text { to }\end{array}$ & Amor & Cielo & Niña & Vida & Corazón \\
\hline Argentina & 1 & 8 & 0 & 0 & 4 & 0 & 2 & 0 & 2 & 0 & 0 \\
\hline Bolivia & 0 & 0 & 0 & 0 & 1 & 0 & 0 & 0 & 0 & 0 & 0 \\
\hline Chile & 0 & 14 & 0 & 0 & 0 & 0 & 11 & 0 & 2 & 0 & 0 \\
\hline Colombia & 1 & 4 & 0 & 0 & 2 & 0 & 12 & 0 & 1 & 3 & 0 \\
\hline Costa Rica & 0 & 0 & 0 & 0 & 0 & 0 & 1 & 0 & 0 & 1 & 0 \\
\hline Cuba & 4 & 11 & 0 & 0 & 0 & 0 & 2 & 0 & 1 & 0 & 0 \\
\hline Ecuador & 0 & 0 & 0 & 0 & 0 & 0 & 0 & 0 & 0 & 0 & 2 \\
\hline Spain & 0 & 0 & 0 & 0 & 6 & 4 & 10 & 2 & 18 & 1 & 0 \\
\hline Guatemala & 0 & 0 & 0 & 2 & 0 & 0 & 0 & 0 & 0 & 0 & 0 \\
\hline Mexico & 14 & 31 & 0 & 27 & 3 & 0 & 2 & 1 & 7 & 2 & 0 \\
\hline Nicaragua & 0 & 1 & 0 & 0 & 0 & 0 & 0 & 0 & 0 & 0 & 0 \\
\hline Paraguay & 1 & 0 & 0 & 0 & 1 & 0 & 0 & 0 & 0 & 0 & 0 \\
\hline Peru & 0 & 16 & 0 & 0 & 0 & 0 & 3 & 0 & 0 & 0 & 0 \\
\hline Puerto Rico & 1 & 0 & 0 & 0 & 0 & 0 & 1 & 0 & 0 & 0 & 0 \\
\hline $\begin{array}{l}\text { Dominican } \\
\text { Republic }\end{array}$ & 1 & 0 & 0 & 0 & 0 & 0 & 0 & 0 & 0 & 1 & 0 \\
\hline Venezuela & 8 & 20 & 3 & 5 & 1 & 0 & 10 & 0 & 3 & 0 & 1 \\
\hline TOTAL & 31 & 105 & 3 & 34 & 18 & 4 & 54 & 3 & 34 & 7 & 3 \\
\hline
\end{tabular}

Table 1: Samples of the use of possessives + nouns as vocatives

As shown in Table 1, the presence of possessives in vocative constructions is not an exception but rather it constitutes a very widespread phenomenon in the Americas and some parts of Spain (e.g. in the Canary Islands). According to this table, there are at least four countries where possessives can appear with the three types of nouns, namely: Argentina, Colombia, Mexico and Venezuela. In these countries, speakers prefer the employment of mi amigo (63 cases) as kinship name, mi jefe (32 cases) or mi señor (10 cases) as title, and mi amor (26 cases) or mi niña (13 cases) as intimate treatment noun. The data in (21), (22) and (23) exemplify this phenomenon. 
(21) Piensa, mi amigo, en la equivalencia

think.IMP my friend.VOC in the equivalence

del cuerpo (México, CREA, 2002).

of-the body

'Think, my friend, in the equivalence of the body'
a. Se lo agradezco, mi jefe, pero... him.DAT it.ACC appreciate my boss.VOC but... estoy de servicio (México, CREA, 1995).
I.am of duty
'I appreciate it, my boss, but ... I'm on duty'
b. Para ti, mi señor, como muestra
for you my lord.VOC as sign de mi obediencia (Venezuela, CREA, 1989). of my obedience 'For you, my lord, as a sign of my obedience'
a. Mi amor, no puedo más (Colombia, CREA, 2002). my love.vOC not can more 'My love, I cannot anymore' close.IMP the eyes my girl.vOC that right now empiezo a contar (Argentina, CREA, 2002). start to count
'Close your eyes, my girl. I'm starting to count'
b. Cierra los ojos, mi niña, que ya mismo

The remaining 12 countries reflect similar conclusions. Thereby, kinship names as mi amigo are especially frequent in countries such as Chile (14 cases), Cuba (11 cases) or Peru (16 cases), followed by mi hijo (31 cases) and mi hermano (3 cases). Nevertheless, no examples of these nouns are found in Peninsular Spanish, which suggests that these expressions are more extended in America than in Europe:
a. Hay que estar
preparados, mi amigo (Chile, CREA, 2002). there-is that be prepared.PL my friend.VOC
'It has to be prepared, my friend'
b. ¿En qué trabajas (...), mi hijo? (Puerto Rico, CREA, 1981). in what you.work my son.VOC
'What's your job, my son?'
c. Eso es talento,mi hermano (Venezuela, CREA, 1999).
this is talent my brother.VOC
'That's talent, my brother'

With regards to hierarchy names, the most common is mi jefe (34 cases) ahead of mi señor (18 cases) and mi sargento (4 cases). Furthermore, some examples are found in Spain (10 cases), which suggests that it is a widespread phenomenon on both sides of the Atlantic. Nevertheless, these cases are grammaticalized to the point of being interpreted as ritualized formulas, possibly because they are used in specific contexts (i.e., sargento in the army in (19)): 
(25) a. Deben de ser del paraíso, mi jefe (Guatemala, CREA, 1994).

must of be from paradise my boss.VOC

'They must be from Paradise, my boss'

b. Mi señor, podemos traer más

my lord.VOC can.PL bring more

hamacas (Colombia, CREA, 1992).

hammocks

'My lord, we can bring more hammocks'

c. Mi sargento, he encontrado algo (España CREA, 2000).

my sergeant.VOC have found something

'My sergeant, I have found something'

Finally, the nouns that denote intimate treatment are one of the most numerous: 94 examples have been found. In Spain (31 cases) they are both numerous and widespread, although they are also grammaticalized. The data presented in Table 1 indicate that the most frequent expressions are mi amor (54 cases) and mi niña (34 cases), followed by mi vida (3 cases), mi cielo (3 cases) and mi corazón (3 cases). Some examples in this regard are offered in (26): my love.VOC what do in the pool'
'My love, what are you doing in the pool?'
a. Mi amor, ¿qué haces en la piscina? (Perú, CREA, 2002).
b. Despiértese, mi niña.
wake-up-you my girl.voc
Soy tu salvador (Venezuela, CREA, 1991).
am your savior
'Wake up, my girl. I am your savior'
c. Mi vida,$(\ldots)$ no sabes lo que he
my life.VOC not know which have
sufrido desde anoche (República Dominicana, CREA, 1980).
suffered since last night
'My life, you don't know how much I've suffered since last night'
d. Mi cielo, ¿has descansado bastante? (España, CREA, 1991).
sweetheart.VOC have rested enough
'Sweetheart, have you rested enough?'
e. Ya ven, mi corazón (Ecuador, CREA, 1988).
yet come, my love.VOC
'Come, my love'

The grammaticalization of these constructions occurs when some words lose part of their descriptive content. For instance, personal pronouns like vosotros ( $2^{\text {nd }}$ person plural: 'you') are the result of a process of joining two elements: a functional category without descriptive content, vos, and a lexical category, otros ('others'), with descriptive content that gradually diminished becoming opaque (Fernández Soriano 1999, among others). The union of both forms resulted in a functional category: a pronoun. 
In the present cases under study, a similar phenomenon could be argued: words like vida ('life), hijo ('son') or jefe ('boss') lose their descriptive content to become a functional category. In other words, they no longer designate an 'existence', 'man with parents' or 'a superior', but when they join the possessive they acquire an affective meaning. As a consequence, a type of recategorization of the descriptive noun produces an 'affective proper name' of the addressee. This explains why the person who employs possessives in vocative constructions may not hold that relationship (father/mother-child, inferior-superior, etc.) with the person to whom it is directed: it is a sign of affection. Therefore, it is not uncommon to find examples of expressions such as mija instead of mi hija ("my daughter') in some Spanish varieties, above all in Latin-America, as shown in (27):

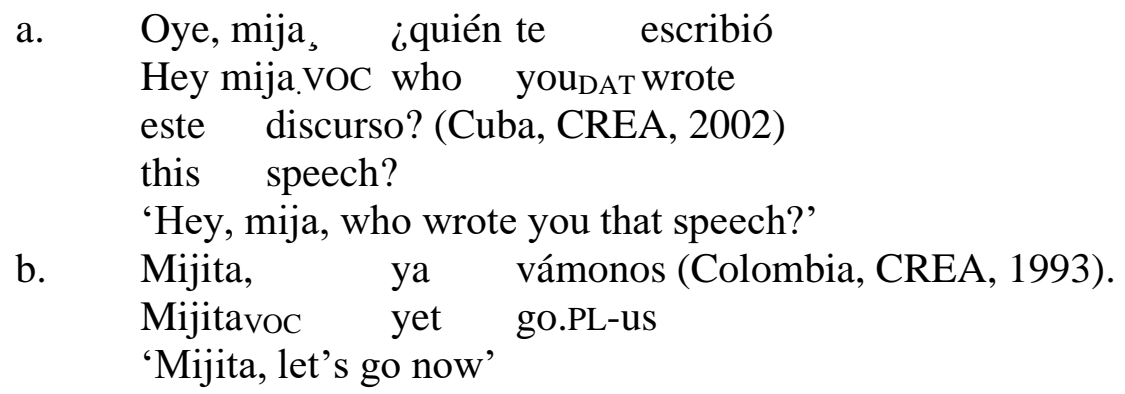

The reason why this phenomenon occurs in some nouns and not in others is due to cultural factors. For instance, in Spanish mi vida ('my life'), corazón mío (lit. heart mine, 'my heart') is used in vocative constructions, but not dulce corazón ('sweet heart'), an expression that is documented in languages such as English (Sweetheart, could you come here?). Hence, grammaticalization becomes an open procedure that may finish by affecting other words.

In sum, the data related to the combination between vocatives and possessives in some Spanish dialects has been presented in this section. However, the question of why some vocatives allow determiners remains unsolved.

\section{Hypotheses}

This section provides some evidence to explain why certain vocatives can be introduced by determiners. Three alternative hypotheses are discussed in turn in the following lines in order to explain the existence of vocatives with determiners in some dialects: (i) that the generalization that Spanish only allow for bare vocatives does not hold across dialects; (ii) that vocatives with determiners are not true vocatives, and (iii) that the possessives appearing in those vocatives are not true determiners.

\subsection{Vocatives in Spanish must be bare}

The first option to take into consideration is that the generalization that Spanish only have bare vocatives does not hold across dialects (see (16)). Therefore, the first hypothesis is the following: 
(28) Vocatives are compatible with determiners in some Spanish varieties.

This is the hypothesis defended in Hill (2013b). She offers an analysis for Romanian vocatives which she then extends to other languages. Her explanation is the following: the definite article is in complementary distribution with the vocative particle, măi or hai in Romanian (in this language, these particles only appear with vocative nouns). In other words, the particle accompanies vocative expressions and, when this particle does not appear, the definite determiner takes its place. Therefore, the configuration that she proposes is shown in (29):

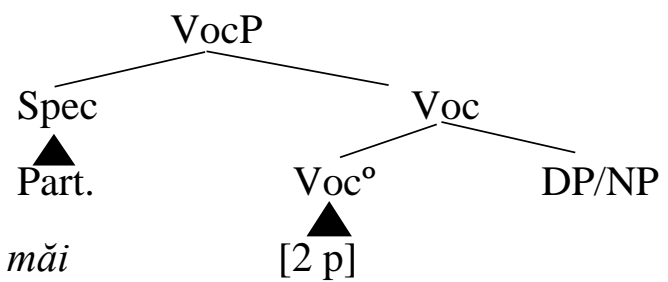

[inter-personal]

As can be seen in (29) vocative projects its own phrase, where the vocative head includes personal (second person) and pragmatic features ([interpersonal]) marked above, and the particle măi occupies the specifier position ([Spec, VocP]). However, when there is no particle, the internal structure of VocP is the following (30): the possessive mea moves from SC to [Spec, AgrP] to check the noun's agreement feature; the noun fat- moves from SC to [Spec, DP] passing over a landing position [Spec, D/PP], and finally, the whole DP moves to [Spec, VocP], space in (29) for the particle măi:

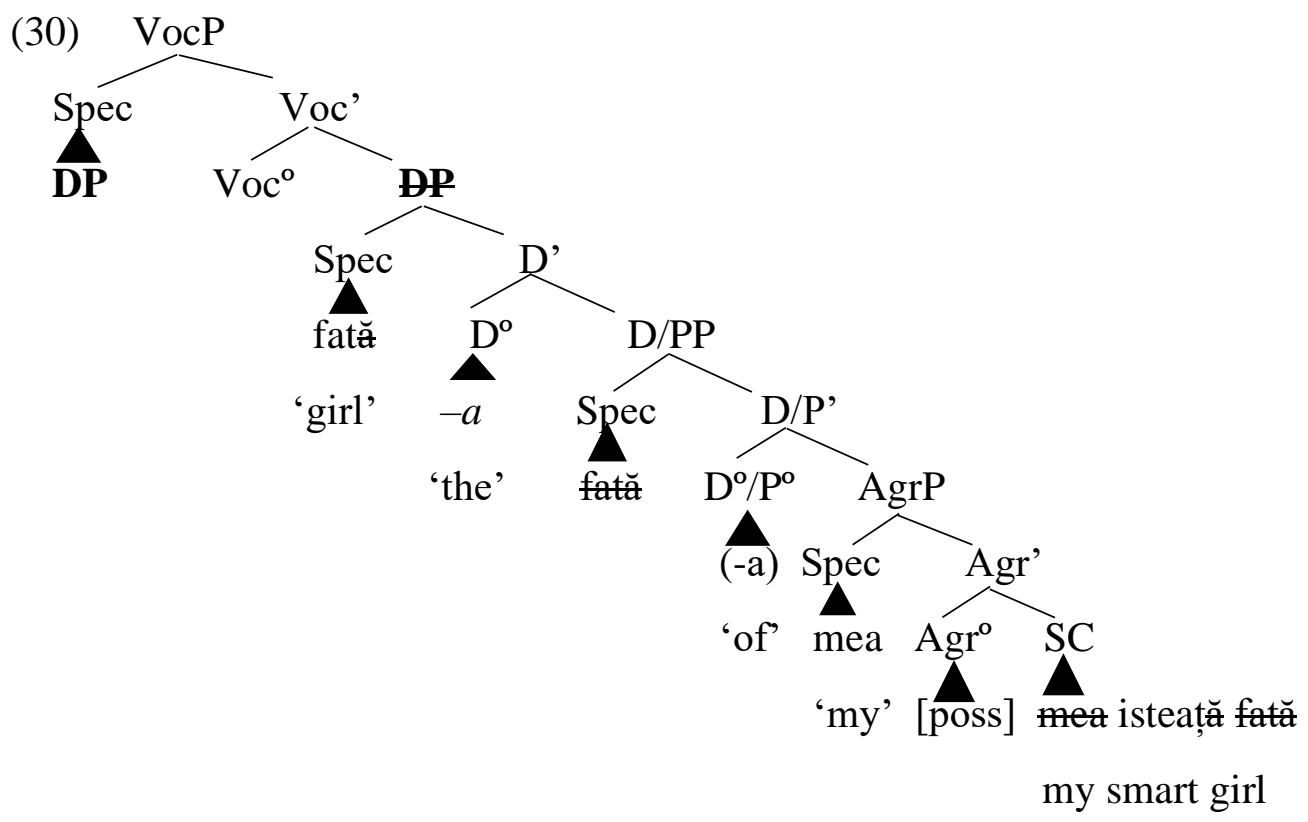

(Hill 2013b: 92) 
If we apply this analysis to the construction under study, vocatives in Spanish are never bare. They are introduced by particle or by a determiner, assuming that the determiner is a type of particle. Therefore, the hypothesis in (28) may be reformulated as follows:

(28') Determiners and, therefore, possessives behave as a kind of particle in vocative constructions.

Nonetheless, this hypothesis faces several problems, since Spanish is a language that differs from Romanian in two aspects: (1) Spanish vocatives cannot be headed by an article (*La niña, deja eso, 'The girl, leave that') as is the case in Bulgarian, Italian, Hungarian and Greek (Stavrou, 2014: 330 and following pages), and (2) the particle is not obligatory in Spanish ((Ei/Eh) Juan, ayúdame con esto, '(Hey) Juan, help me with this'). Furthermore, if hypothesis 1 were correct, it would suppose that vocatives are compatible with other determiners in some Spanish varieties. Nevertheless, we have not found any of the examples shown in (31), which suggests that vocatives remain incompatible with other determiners, so the hypothesis is rejected:

(31) Vuelvea casa, $\left\{\begin{array}{c}\text { *la/*esta } \\ \text { the/this, }\end{array}\right.$ that/that/ aquella/*una/*alguna $\}$
return to home,
hija.
daughter.vOC
'(intended) Come back home, daughter'

In conclusion, Hill's hypothesis may work in those languages built with determiners (e.g. in Romanian and French as Stavrou, 2014 points out) but not in Spanish, so this hypothesis should be discarded.

\subsection{Possessive vocatives in Spanish are fake vocatives}

The second hypothesis supposes that the generalization in (16) is correct and explains the data in terms of true/fake vocatives: some determiners like possessives can introduce these constructions because they are, in fact, fake vocatives (Espinal 2013). As a consequence, the hypothesis may be the following:

\section{Vocative constructions headed by possessives are fake vocatives.}

Thus, it is necessary to distinguish between true vocatives and fake vocatives. This distinction is made by Espinal (2013) in her research about Catalan vocatives. Espinal points out the necessity for two types of vocatives: true vocatives (second person pronouns, proper names, bare nouns and adjectives) and fake vocatives (DP and QP: Tots vosaltres, veniu/ Todos vosotros, venid, 'All of you, come here', Espinal 2013: 4). True vocatives occupy the $\operatorname{Voc}^{\mathrm{o}}$ position, appear optionally specified by a particle (PART), designate the addressee directly, and move from $\mathrm{A}^{\mathrm{o}}, \mathrm{N}^{\mathrm{o}}$ or $\mathrm{D}^{\circ}$ (head to head movement) to $\operatorname{Voc}^{\circ}$ to check the deictic feature $([+\mathrm{DX}])$ and to guarantee deictic interpretation (Espinal 2013: 4). In 
contrast, fake vocatives occupy two different positions: in most cases [Spec, VocP] and sometimes [Spec, DP] when they appear with a vocative particle, although this last option is quite unusual (Espinal 2013: 5). They cannot be in $\mathrm{Voc}^{\circ}$ because they are not heads, they are in syntactic relation with a null vocative, which checks deictic features, and their meaning is associated with a predicative or quantificational interpretation (Espinal 2013: 4-6). This proposal is illustrated in (33):

\section{[VocP PART/Fake Voc $\left[\operatorname{Voc}^{\circ}\right.$ True Voc $[+\mathrm{DX}]\left[\mathrm{DP}\right.$ Fake Voc $\left.\left.\left[\mathrm{D}^{\circ}\right]\left[\mathrm{NP}\left[\mathrm{N}^{\circ}\right]\right]\right]\right]$}

This hypothesis can account for controversial issues such as how it can be explained why determiners appear in vocative constructions in some contexts: they are, in fact, fake vocatives which are complements of a null $\mathrm{Voc}^{\circ}$. It would be this null $\mathrm{Voc}^{\mathrm{o}}$ that would check the deictic features and, as a consequence, would guarantee the vocative interpretation. Thus, this hypothesis would explain why constructions such as El chico de la última fila, sal de clase ('The boy in the last row, leave class') are possible in Spanish as evidenced by the fact that the pronoun can be recovered without producing changes in meaning: Tú, el chico de la última fila, sal de clase ('You, the boy in the last row, leave class')

If we apply this proposal to vocative constructions with possessives, they will fit in fake vocatives, due to being DPs. Nevertheless, changes in meaning occur when the pronoun is recovered. For instance, when mi niña ('my girl') or $m i$ cielo ('my dear') are used, it is uttered with an affective sense, indicating closeness and affection (34a). However, as long as the pronoun is recovered, the meaning will change into something close to reproach, anger or maybe strangeness, which would give rise to contradictory expressions such as those that appear in (34b):

$$
\begin{aligned}
& \text { a. Mi niña, ¿vas a ayudarme? } \\
& \text { my girl.voC go to help-me } \\
& \text { 'My girl, are you going to help me?' } \\
& \text { b. ?Tú, mi niña, ¿vas a ayudarme? } \\
& \text { you.voC my girl go to help-me } \\
& \text { 'You, my girl, are you going to help me?' }
\end{aligned}
$$

Something similar happens in Romanian if we combine a formal particle with a vocative case ending (-e), or an article, since the former has a formal meaning whereas the latter, an informal sense (see section 2). Therefore, the reason for the incompatibility between mi niña and the pronoun tú is due to the fact that they do not share the same pragmatic properties and, as a consequence, they have different inter-personal features.

Hence, if the presence of the null pronoun $\operatorname{Voc}^{\circ}$ cannot be compatible with a DP headed by a possessive, the only possible analysis that remains is to hold that these constructions constitute deictic expressions in themselves; that is, they would be interpreted as true vocatives. However, this statement would suppose a paradox within Espinal's analysis: some structures are interpreted as true vocatives while having the appearance of fake vocatives (they are DPs). Moreover, they do not obey the established conditions of being interpreted as true 
vocatives (they should be bare nouns to have the chance to move to $\operatorname{Voc}^{\circ}$.). Therefore, Espinal's analysis does not account for the properties of possessive vocatives in some Spanish varieties.

\subsection{Possessives in non-bare vocatives are not real determiners}

As discussed in previous sections, vocatives with determiners are not possible in Spanish except if the determiner is a possessive. If this hypothesis is correct, possessives do not provide referential meaning to vocative expressions, as evidenced by the fact that they can be omitted, but nouns are still referential by themselves, as shown in (35) and (36):
a. $\mathrm{Me}$
han contado
cosas de tu vida,
me.DAT
have told
things of your life
mi amiga (Cuba, CREA, 2002, Álvarez Gil, Antonio: Naufragios).
my friend.VOC
'They have told me things about your life, my friend'.
b. Me han contado cosas de tu vida, amiga. me.DAT have told things of your life friend.VOC
'They have told me things about your life, friend'
a. Mi amor, no puedo más (Colombia, CREA, 2002).
my love.VOC not can more
'My love, I cannot bear it anymore'
b. Amor, no puedo más.
love.vOC not can more
'Love, I cannot bear it anymore' follows:

Taking into account these examples, hypothesis 3 can be formulated as

(37) Possessives are not true determiners, which explains why they can introduce vocative constructions.

Nevertheless, the idea that possessives are not true determiners is not new. The literature has already been pointed out some differences between possessives and determiners. In what follows, a classification of these differences is offered depending on whether they are related to their properties or to their capacity of combination.

With regards to the possessives' features, Leonetti $(1999,2016)$ points out some important properties that make it possible to tell apart possessives from true determines. First of all, possessives have an autonomous reference $\left(*\left[m i_{\mathrm{i}}\right.\right.$ profesor $]_{\mathrm{i}}$ - 'my teacher'-: Leonetti 1999: 81), while true determiners do not ([el profesor $]_{\mathrm{i}}$-'the teacher'-). Secondly, possessives are argumental (su hija $=$ 'su hija de él/ella'; his/her daughter = 'the daughter of he/she') or adjunct complements of the noun ( su casa = 'su casa de él'; his/her house = 'the house of she/he'), whereas true determiners are never complements to the noun (\{La/esa/esta/aquella\} hija: ' $\{$ The/This/That\} girl'). Finally, true determiners are generated in prenominal position ([SD $L a$ [SN niña]]: 'The girl'), which contrasts with the fact that possessives are generated in postnominal position ([t $u_{i}$ hermano 
$\left.h_{i}\right]=t u$ hermano de él > tu hermano; 'your brother $>$ the brother of he). In this respect, different analyses have been offered, which are summarized in the work of Brucart (1994) and Eguren (2017).

Brucart (1994: 59) proposes that possessives are generated in postnominal position and they then move to [Spec, DP] (see also Leonetti 1996, 2016) ${ }^{10}$ :

$$
\begin{aligned}
& {\left[\mathrm{DP}\left[\mathrm{Spec} \mathrm{mi}_{\mathrm{i}}\right]\left[\mathrm{D}^{\prime}\left[\mathrm{D}^{\circ} \varnothing\right]\left[\mathrm{NP}\left[\mathrm{Spec} \mathrm{h}_{\mathrm{i}}\right]\left[\mathrm{N}^{\prime}\left[\mathrm{N}^{\circ} \text { alumno } \mathrm{h}_{\mathrm{i}}\right]\right]\right]\right]\right.} \\
& \text { 'my student }
\end{aligned}
$$

(Brucart 1994: 59)

Eguren (2017), following Brucart (1994) and Cinque (2010), proposes two possibilities in possessive generation depending on the language: postnominal and prenominal possessives. Postnominal possessives remain in-situ and it is the noun, $\mathrm{N}$, that moves across them, as can be seen in (39) ${ }^{11}$ :

$$
\begin{aligned}
& \text { [DP [D } \left.\left.\left.\left.\left.\mathrm{Dl}] \ldots \text { [NumP [Num libroj] [PossP mío [Poss } \mathrm{t}_{\mathrm{j}}\right] \ldots \text { [NP [N } \mathrm{t}_{\mathrm{j}}\right]\right]\right]\right] \\
& \text { The book mine } \\
& \text { 'my book' }
\end{aligned}
$$

(Eguren 2017)

Prenominal possessives present two possibilities: the first one is found in languages such as Italian whose structure is 'Determiner + Possessive + Noun', while the second one is documented in languages such as European Spanish and French, where possessives cannot be preceded by determiners (i.e. 'Possessive + Noun'). In the first case (40), possessive (Poss), generated in postnominal position, moves to the [Spec, AgrP] attracted by agree feature. In the second case (41), possessives, also generated in a postnominal position ([Spec, PossP]), move first to [Spec, AgrP], to check agree properties, and then to [Spec, DP], to check definiteness features (Eguren 2017). These structures are shown in (40) and (41) respectively:

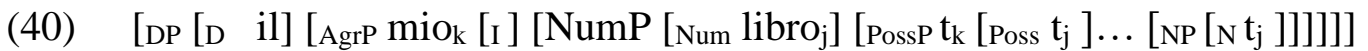
the mine book 'my book'

(41) $\left[\mathrm{DP} \mathrm{mi}_{\mathrm{k}}\right.$ [D’ [D Ø] [AgrP $\mathrm{t}_{\mathrm{k}}[\mathrm{I}]$ [NumP [Num libro $\mathrm{j}$ [PossP $\mathrm{t}_{\mathrm{k}}\left[\mathrm{Poss} \mathrm{t}_{\mathrm{j}}\right] \ldots$ [NP [N $\left.\left.\left.\left.\left.\left.\mathrm{t}_{\mathrm{j}}\right]\right]\right]\right]\right]\right]$ 'my book'

(Eguren 2017)

Regarding their capacity of combination, possessives also differ from the true determiners in being able to appear with other determiners in some Spanish varieties, as Brucart (1994) points out (42a), while true determiners cannot (42b):

10 For discussion of how anti-locality restrictions are met in this derivation, see Brucart (1994: 59).

11 According to Eguren (2017), this hypothesis is postulated in Brito (2007) for Portuguese, in Bernstein (2001) for Spanish and in Cardinalletti (1998) for Italian. 

a. estos mis hijos ${ }^{12}$
these my children
'my children'
b. *los estos hijos
the these children
'(intended) the/these children'

Possessives can also combine with explicative relative sentences (43a), but not with restrictive relatives (43b), another characteristic that differentiates them from determiners (43c):
a. $\quad \underline{\text { Su móvil, }}$
que me
dio Ana, es bonito.
her mobile phone that me.DAT gave Ana is beautiful
'Her/his mobile phone, that Ana gave me, is beautiful'
b. $\quad \stackrel{\mathrm{Su}}{\mathrm{Su}}$ móvil que me dio Ana es bonito.
her mobile phone that me.DAT gave Ana is beautiful
'(intended) Her/his mobile phone that Ana gave me is beautiful'
c. El móvil que me dio Ana es bonito.
the mobile phone that me.DAT gave Ana is beautiful
'The mobile phone that Ana gave me is beautiful'

The impossibility of combination with restrictive relatives has been explained in two different ways: because of the violation of the Incidence Principle of modifiers (Higginbotham 1985) as Brucart (1994: 78) defends (44) ${ }^{13}$, and due to the infringement of the Condition on Extraction Domains (Lasnik \& Saito 1992) as Eguren points out, see (45) ${ }^{14}$ :
a. $\quad *\left[\mathrm{DP} \quad \mathbf{S u}_{\mathbf{i}}\left[\mathrm{NP} \mathbf{h}_{\mathbf{i}}\left[\mathrm{N}^{\circ}\right.\right.\right.$ conquista $\mathbf{h}_{\mathbf{i}}$ de Roma $\left.\left.\left.\mathbf{h}_{\mathbf{i}}\right]\right]\right]$
her/his conquest of Rome
'her/his conquest of Rome'
b. [DP $\mathbf{S u}_{\mathbf{i}}\left[\mathrm{NP} \mathbf{h}_{\mathbf{i}}\left[\mathrm{N}^{\circ}\right.\right.$ conquista de Roma $\left.\left.\left.\mathbf{h}_{\mathbf{i}}\right]\right]\right]$
a. $\quad{ }^{?} \mathrm{Su}$ libro que me prestó
her/his book that me.DAT lent 'her/his book that he/she lent me

(Brucart 1994: 78).

b. [DP $\mathbf{S u}_{\mathbf{j}}\left[\mathrm{D}^{\prime}[\mathrm{D} \varnothing]\left[\mathrm{CP}\left[\mathrm{XP} \text { libro } \mathbf{t}_{\mathbf{j}}\right]_{\mathbf{i}}\left[\mathrm{C}^{\prime}\right.\right.\right.$ que me prestó $\left.\left.\left.\mathrm{t}_{\mathbf{i}}\right]\right]\right]$

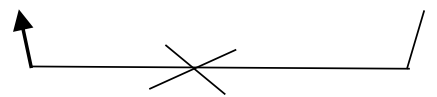

(Eguren 2017: 15)

$12 \quad$ From Brucart (1994: 59).

13 Analysing Brucart's proposal, Eguren indicates that this construction “(...) is ungrammatical because the relative clause, which follows all restrictive modifiers in a nominal expression, does not c-command the raised possessive" (Eguren 2017).

14 According to Eguren, what happens in these structures is that "[Spec, CP] renders syntactic objects in this position internally frozen (i.e. they can be extracted as a whole, but their subparts cannot be extracted)" (Eguren 2017). 
Therefore, we can conclude that possessives are not true determiners, which explains why they can appear in vocative constructions in some Spanish varieties. In the next section, I propose a formal analysis which captures this intuition.

\section{Analysis}

To explain how these properties affect our analysis, we have divided the following section into two parts: analysis with a postnominal possessive (§4.1.) and analysis with a prenominal possessive (\$4.2.).

\subsection{Vocatives with postnominal possessives}

Based on the analysis in Espinal (2013) and Hill (2013b) examined in previous sections, I propose the existence of a Vocative Phrase (VocP), whose head, $\mathrm{Voc}^{\mathrm{o}}$, has a series of features that allows constructions to be identified as such. These features are the following: on the one hand, $2^{\text {nd }}$ person, intrinsically deictic, and number (singular or plural) due to their link with the addressee; on the other hand, its inter-personal ([i-p]) pragmatic property, proposed by Hill (2013a, 2013b). The last one shows the kind of relationship between speaker and hearer, and triggers some syntactic operations, which have been explained in section 1. The representation in (46) illustrates this proposal:

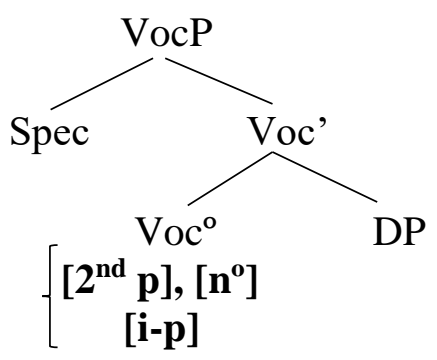

As can be seen in (46), $\operatorname{Voc}^{\mathrm{o}}$ takes as a complement a Determiner Phrase (DP), whose head, $\mathrm{D}^{\circ}$, can be full by a discourse participant (tú -'you' sing. - or vosotros -'you' pl.-) or, for instance, a proper name (see Longobardi, 1994), since they are necessarily definite on their own, referential and specific, all these features are compatible with those of the vocative head, $\operatorname{Voc}^{\circ}$ (see section 1). However, possessive structures such as mi niño ('my son') cannot behave in the same way for several reasons. In the first place, possessives are not true determiners, as Leonetti or Brucart, among others, point out. Furthermore, possessives do not provide the noun with any feature of definiteness, referentiality or specificity, as evidenced by the fact that, if they are omitted, the noun retains all those features as it has been explained in previous sections. Finally, if they checked [+/- definiteness] features, they would link to the discourse ([D-linked)] and, therefore, they would be incompatible with $\mathrm{Voc}^{\circ}$ properties since vocatives cannot refer to an entity previously said: they are in a level above the discourse (it would be necessary to turn to it to assign reference to the indefinite element). 
Hence, it could be postulated that $\mathrm{D}^{\circ}$ remains empty in these constructions, as it is shown in (47):

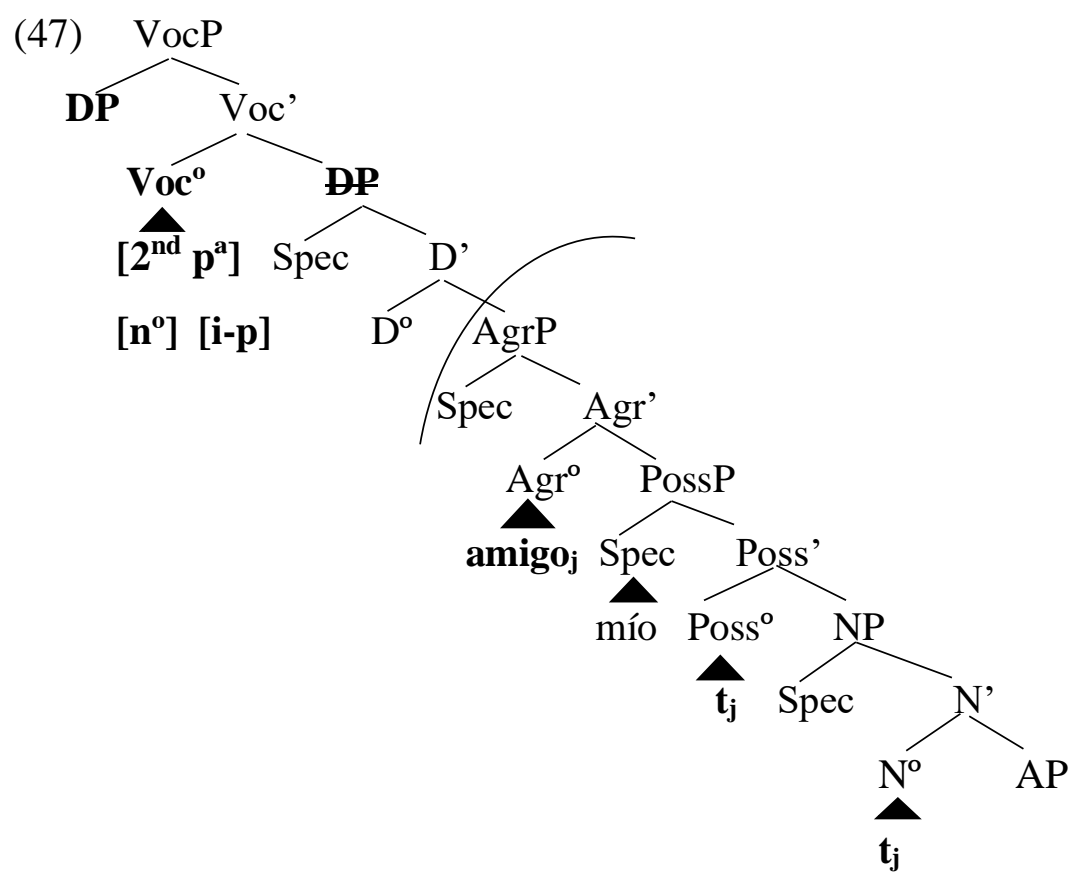

The analysis of (47) shows that possessives are generated in a postnominal position, [Spec, PossP], as Leonetti (1999) and Brucart (1994) propose, and remain in-situ, as Cardinaletti (1998), Bernstein (2001) and Brito (2007) assert. The noun moves through them to $\mathrm{Agr}^{\circ}$ to check agree features (gender and number). As proposed in Hill (2013b), the vocative interpretation is obtained by the movement of the whole DP to [Spec, VocP] to check the features of $\mathrm{Voc}^{\mathrm{o}}$ head (i.e. $2^{\text {nd }}$ person, number and inter-personal) ${ }^{15}$. Due to their phrase nature, DP cannot move to $\mathrm{Voc}^{\circ}$, since if it were the case, Principle of Movement Uniformity would be violated: DP is a phrase, not a head.

Having established the analysis of constructions with postnominal vocatives, in the next section it will examine the position of prenominal possessives.

\subsection{Vocatives with a prenominal possessive}

In the previous section we have shown the position of postnominal possessives (amigo mio = 'friend mine'): they are generated in postnominal position ([Spec, PossP]) and remain in-situ. However, when they are prenominal they should move from [Spec, PossP] to [Spec, AgrP] to check gender and number features of the noun that they modify, but not to [Spec, DP] or [ $\left.\mathrm{D}^{\circ}, \mathrm{DP}\right]$, as explained previously. Thereby, the analyses presented by Leonetti (1999) and Eguren (2017) have been maintained, since they defend that possessives are generated in a postnominal position and move to a functional category over NP when they are prenominal, as Cinque (2010) proposes for adjectives.

15 For discussion of how anti-locality restrictions are met in this derivation, see Hill (2013b). 
Finally, the present paper propose that the whole DP moves to [Spec, VocP] to check $\mathrm{Voc}^{\circ}$ features (i.e. second person -singular or plural- and interpersonal properties) that allow them to have a vocative interpretation, in the same line of Hill's analysis. Therefore, the final configuration of these constructions is illustrated in (48):

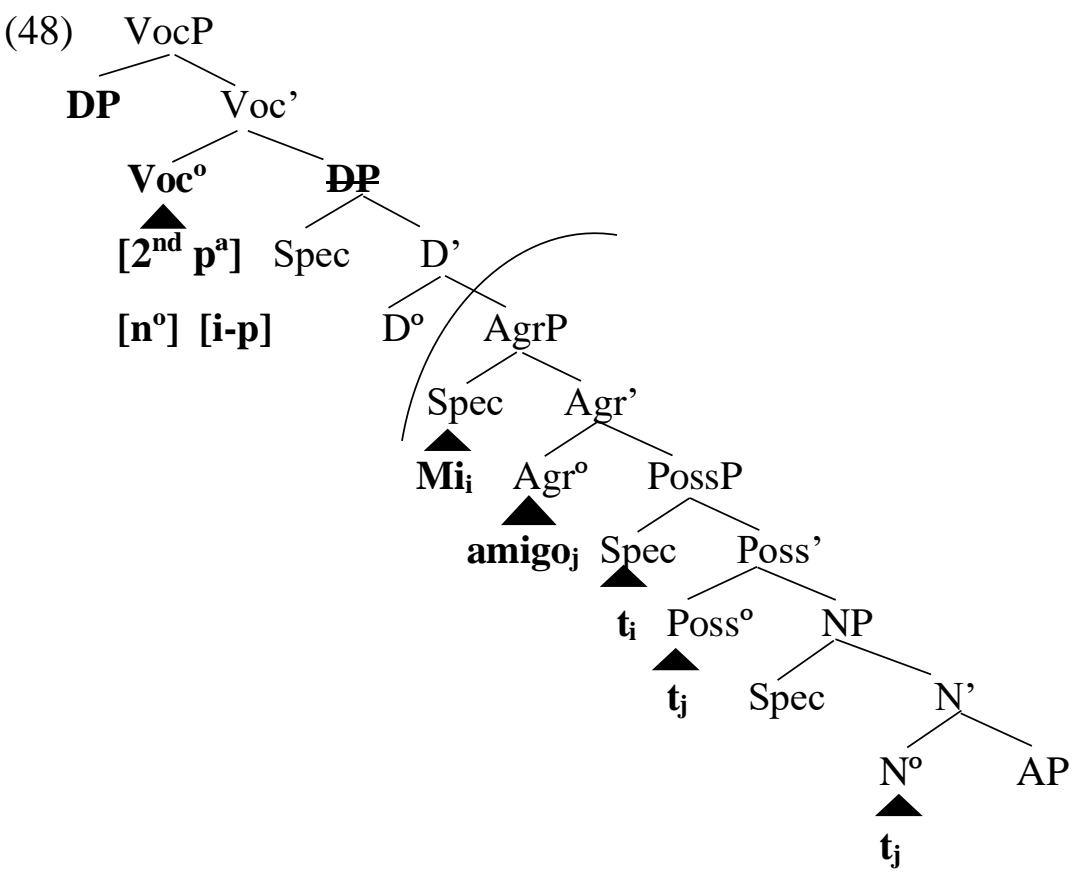

If this analysis is on the right track, it would explain the variation found in Spanish: in those varieties in which possessives are compatible with a true determiner (un mi amigo que es muy pobrecito, lit. 'a my friend that is very poor', Eguren 2017), we obtain a prenominal possessive in vocatives (mi amigo que es muy pobrecito, lit. 'my friend that is very poor') as a result of the possessive's movement to [Spec, AgrP] (amigo mío $>\underline{m i_{i}}$ amigo $\mathrm{h}_{\mathrm{i}}$ ) and the whole DP to [Spec, VocP]. On the contrary, in varieties which are not compatible with them (un amigo mío, lit. 'a friend mine'), we predictably find a postnominal possessive in the vocatives' construction (amigo mío, lit. 'friend mine/of mine'). ${ }^{16}$

\section{Conclusion and future research}

The present paper has offered a description of grammatical variations that have not been studied in detail from a syntactic point of view until now. In particular, a syntactic analysis of vocatives is proposed in line with current research (Espinal 2013, Hill 2013b among others). In this line of analysis, possessives are generated in postnominal position and remain in-situ when they are postnominal (amigo mío, lit. 'friend mine/of mine'). In contrast, possessives move to [Spec, AgrP] to check number and gender when they are prenominal (mi amigo, lit. 'my friend'). Therefore, our analysis is compatible with proposals by Brucart (1994), Leonetti

16 Nevertheless, it would be necessary to carry out a deeper investigation in the future that would support these data. 
(1999, 2016) and Eguren (2017), and in addition, it completes the data proposed by Eguren for American Spanish (in bold):

- American Spanish: compatibility of possessives with PP postposed possessives (su hermana de él $=$ 'his sister of him'), restrictive relatives ( $s u$ hermana que se llama Ana = 'her/his sister called Ana'), preceding determiners ( $\underline{\text { una }}$ su hermana $=$ 'a his/her sister') as well as the availability of prenominal possessives in vocative constructions ( $m i$ hermana $=$ 'my sister').

- European Spanish: availability of PP with postnominal possessives (la hermana de él $=$ 'the sister of him'), incompatibility of possessives with restrictive relatives ( su hermana que se llama Ana = 'her/his sister called Ana'), compatibility with postnominal possessives (una hermana suya $=$ 'a sister of his/her') and availability of postnominal possessives in vocative constructions (hermana mía $=$ 'sister mine').

Finally, the present analysis opens new lines of future research in relation to the analysis that possessives are not true determiners in which it becomes necessary to determine which position possessives occupy within the DP. Furthermore, the necessity of resolving the issue related to vocatives is shown: why they cannot be introduced by a determiner, and what its internal structure and referential nature is, among other things. Therefore, it is necessary to carry out studies that analyze in depth all these and other similar questions where vocatives are given the importance they deserve in grammar.

\section{References}

Alonso Cortés, A. 1999. Las construcciones gramaticales. La interjección y las expresiones vocativas. In I. Bosque, and V. Demonte (eds.), Gramática descriptiva de la lengua española, vol. III, 3993-4050. Madrid: Espasa Calpe.

Bañón, Antonio Miguel. 1993. El vocativo en español. Propuesta para su análisis lingüístico. Barcelona: Octaedro SL.

Bernstein, Judy B. 2001. Focusing the "right" way in Romance determiner phrases. Probus 13(1): 1-29. DOI: 10.1515/prbs.13.1.1

Bosque, Ignacio. 1996. El sustantivo sin determinación. Madrid: Visor Libros.

Brito, Ana Maria. 2007. European Portuguese possessives and the structure of DP. Cuadernos de Lingüística del I.U.I. Ortega y Gasset 14: 27-50.

Brucart, José María. 1994. Sobre una incompatibilidad ente posesivos y relativas especificativas. In V. Demonte (ed.), Gramática del español, 51-86. México: Colegio de México.

Cardinaletti, Anna. 1998. On the deficient/strong opposition in possessive systems. In A. Alexiadou, and C. Wilder (eds.), Possessors, predicates and movement in the Determiner Phrase, 17-53. Amsterdam: John Benjamins.

Cinque, Guglielmo. 2010. The syntax of adjectives: A comparative study. Cambridge, MA: MIT Press.

D’Hulst, Yves, Martine Coene, and Liliane Tasmowski. 2007. Romance vocatives and the DP hypothesis. In A. Cuniță, C. Lupu, and L. Tasmowski (eds.), Studii de lingvistică și filologie romanică: hommages offerts á Sandra Reinherimer: 200-211. Bucharest: Editura Universităţii din București. 
Eguren, Luis. 2017. Possessives and relative clauses in Spanish. Probus 29(1): 4172. https://doi.org/10.1515/probus-2015-0006

Eguren, Luis., and Sánchez López, Cristina. 2003. La gramática de otro. Revista Española de Lingüística 33(1): 69-122.

Eguren, Luis, and Sánchez López, Cristina. 2007. Imprecisión extensional e imprecisición intensional: la gramática de cierto. Verba. Anuario galego de filoloxia 34: 99-124.

Espinal, M. Teresa. 2013. On the structure of vocatives. In B. Sonnenhauser, and P. Noel (eds.), Vocative!, 109-132. Berlín: Mouton de Gruyter.

Fernández Soriano, Olga, 1999. "El pronombre personal. Formas y distribuciones. Pronombres átonos y tónicos". In I. Bosque, and V. Demonte (eds.), Gramática descriptiva de la lengua española, vol. I, 1209-1273. Madrid: Espasa Calpe.

Fink, Robert. 1972. Person in nouns: is the vocative a case?. American Journal of Philology 93(1): 61-68.

Haegeman, Liliane. 2014. West Flemish verb-based discourse makers and the articulation of speech act layer. Studia Linguistica 68: 116-139. DOI: $10.1111 /$ stul.12023.

Haegeman, Liliane, Hill, Virginia. 2013. The Syntacticization of Discourse. In R. Folli, C. Sevdali, and R. Truswell (eds.), Syntax and its Limits, 370-390. Oxford: Oxford University Press. DOI: 10.1093/acprof:oso/9780199683239.003.001.

Higginbotham, James. 1985. On Semantics. Linguistic Inquiry 16: 547-593.

Hill, Virginia. 2012. Complementizers and verb-second. A main clause complementizer. In L. Aelbrecht, L. Haegeman, and R. Nye (eds.), Main Clause Phenomena, 279-296. Amsterdam: New Horizons.

Hill, Virginia. 2013a. Features and strategies: the internal syntax of vocative phrases. In B. Sonnenhauser, and P. Noel (eds.), Vocative! Addressing between system and performance, 133-155. Berlín: Mouton de Gruyter.

Hill, Virginia. 2013b. How Syntax meets with Pragmatics, vol. V. Leiden-Boston: Brill.

Lasnik, Hovard, and Saito, Mamuro. 1992. Move $\alpha$ : conditions on its applications and outputs. Cambridge, MA: MIT Press.

Leech, Geoffrey. 1999. The distribution and function of Vocatives in American and British English conversation. In H. Hasselgard, and S. Oksefjiell (eds.), Conversation of corpora: studies in honour of Stig Johansson, 107118. Amsterdam: Rodopi.

Leonetti, Manuel. 1990. El artículo y la referencia. Madrid: Taurus.

Leonetti, Manuel. 1999. Los determinantes. Madrid: Arco Libros S.L.

Leonetti, Manuel. 2016. Determinantes y artículos. In J. Gutiérrez-Rexach (ed.), Enciclopedia lingüística hispánica, vol. I, 532-543. Nueva York: Routledge.

Longobardi, Giuseppe. 1994. Reference and Proper Names: A Theory of NMovement in Syntax and Logical Form. Linguistic Inquiry, 25(4): 609665.

Lyons, John. 1977. Semántica. Barcelona: Teide.

Moro, Andrea. 2003. Notes on Vocative Case: A Case Study in Clause Structure. In J. Quer, J. Schroten, M. Scorretti, P. Sleeman, and E. Verheugd (eds.), 
Romance Languages and Linguistic Theory: 247-261. Amsterdam: John Benjamins.

Real Academia Española y Asociación de Academias de la Lengua Española. 2009. Nueva gramática de la lengua española. Madrid: Espasa.

Real Academia Española: Banco de datos (CREA). Corpus de referencia del español actual. [online] <http://www.rae.es> [March of 2017]

Stavrou, Melita. 2014. About the vocative. In L. Schürcks, A. Giannakidou, and U. Etxeberria (eds.), Studies in Generative Grammar [SGG]: The Nominal Structure in Slavic and Beyond, 299-342. Berlin/Boston, US: De Gruyter Mouton.

Schwarz, Florian. 2009. Two types of Definites in Natural Language. PhD in Massachusetts University.

Variel, Helene. 1981. The position of the vocative in the Latin case system. American Journal of Philology 102: 438-447. 